\title{
Well-Being and Working Conditions of Teachers in Sweden
}

\author{
Elinor Schad*, Per Johnsson \\ Department of Psychology, Lund University, Sweden \\ ${ }^{*}$ Corresponding author. E-mail: elinor.schad@psy.lu.se
}

Background. In Sweden, teachers are subject to high turnover, unfavorable working conditions, and high incidence of stress-related disorders. The aim of the present study was to (a) assess teachers' perceptions of work-related health and working conditions, (b) examine the relationship among several key characteristics in teachers' work environment, and (c) examine the importance for well-being of job satisfaction, separation between work and spare time, and recovery from work.

Design. Primary and lower secondary school teachers in Sweden were invited to participate in a questionnaire study assessing five central aspects of health (subjective well-being, physical activity, self-rated health, sleep quality, and health complaints). Building on previous research, the effect of job satisfaction on well-being as well as on health complaints was tested using a mediation model with separation between work and spare time, and recovery from work, as mediators.

Results. Of the respondents, $40.2 \%$ scored below the cut-off recommended in the screening for depression, $43.8 \%$ qualified as leading a sedentary lifestyle, and $33.7 \%$ reported insufficient recovery from work. Sixtyone percent reported one or more sleep problems indicative of insomnia. Well-being correlated highly with self-rated health, health complaints, and separation between work and spare time. There is moderate support for the two models used to analyze the associations between job satisfaction and the outcome variables - well-being and health complaints - as both separation between work and spare time, and recovery from work, partially mediate the associations.

Conclusion. The results confirm recent research pointing to the teaching profession as a vulnerable occupational group. Especially disconcerting and relevant for teachers in Sweden are results indicative of problems with recovery from work and insufficient separation between work and spare time.
Keywords:

health complaints; job satisfaction; recovery from work; self-rated health; separation between work and spare time; Sweden; teachers; WHO-5 


\section{Introduction}

Teachers in Sweden have experienced cutbacks and reforms in recent years, altering teaching conditions in substantial ways (Lundström, 2015). Notwithstanding that many teachers like their job, there are a number of reports indicating a problematic work situation (Arbetsmiljöverket, 2014b, 2016; Försäkringskassan, 2014). This negative trend is in line with international data (Travers, 2017). Compared to ten years ago, teachers experience a higher workload and increased demands (Fromm \& Hagström, 2011). Sleeping problems, sick leave, and intention to quit their job are also issues that have been reported (Arbetsmiljöverket, $2014 \mathrm{~b}$ ). To this can be added that the teaching profession is increasingly scrutinized by society at large, which puts collective pressure on teachers as a group. Although recent national studies have investigated the occurrence of problems with teachers' health by studying burnout (Arvidsson, Håkansson, Karlson, Björk, \& Persson, 2016), work-life conflict (Richter, Näswall, Lindfors, \& Sverke, 2015), and workplace communication (Schad, 2019a; Schad 2019b), there is a need to further assess the associations between the work environment of teachers and teachers' well-being and health.

\section{Work-Related Health}

In light of recent reports about health and sick leave among teachers in Sweden, there is an apparent need for a comprehensive assessment of teachers' health. To this end, indicators for well-being, physical activity, self-rated health, sleep quality, and health complaints were used as five central aspects to assess teachers' perception of their own health. Separation between work and spare time, possibilities for recovery from work, estimation of work ability, and sick leave were further investigated, in order to get a full picture.

\section{Subjective Well-Being}

People's well-being is associated with their physiology (Ryff \& Singer, 1998), ability to cope with stress (Salovey, Rothman, Detweiler, \& Steward, 2000), and longevity (Chida \& Steptoe, 2008). Satisfying social relationships, being productive at work, and being active in society are some of the behavioral consequences reported for people with high subjective well-being (for a review, see Diener, Tay, \& and Oishi, 2017). Furthermore, work-related well-being was shown, in a longitudinal study by Hakanen and Schaufeli (2012), to predict general well-being.

Well-being can be measured and quantified in several areas of life (e.g., physical, emotional, social, and spiritual) (McDowell, 2010). Subjective well-being (SWB) refers to psychological functioning in three areas (life satisfaction, positive mood, and absence of negative mood) (Diener, Oishi, \& Lucas, 2003). Subjective well-being is frequently measured using the World Health Organization WellBeing Index (WHO-5) (Topp, Østergaard, Søndergaard, \& Bech, 2015). The scale is a positively worded five-item questionnaire assessing well-being during the past two weeks (Bech, 1999).

The WHO-5 has, in terms of clinimetric validity and as a distinctly generic scale, proven, in comparison with other well-being measures, to be free of overlap 
with other specific disease-related aspects (Hall, Krahn, Horner-Johnson, \& Lamb, 2011). In addition, the WHO-5 has proven to have high sensitivity for the screening of depression, and is therefore often recommended as a screening tool, whether for clinical diagnostic use or for research purposes (Topp et al., 2015).

\section{Physical Activity}

The many benefits of physical activity are well established (Warburton, Nicol, \& Bredin, 2006); yet, life today is increasingly sedentary. The WHO definition of physical activity specifies being active as: ">150 minutes/week of physical activity such as for example gardening or brisk walks" (WHO, 2010). Recent national surveys in Sweden indicate that physical activity on the population level has remained steady during the past ten years (Folkhälsomyndigheten, 2016). It is worth noting that for both men and women, educational level correlates with physical activity, as those with higher educational levels also report higher levels of physical activity (Loyen et al., 2016). Teachers can be presumed to have a fairly active work days compared to many other professionals.

\section{Self-Rated Health}

The WHO defines health as a "state of complete physical, mental and social wellbeing and not merely the absence of disease or infirmity" (WHO, 1948). In order to assess health in epidemiological research, various measures with self-ratings are commonly used (Eriksson, Undén, \& Elofsson, 2001). Although the use of such self-ratings has been criticized, a recent comparative study has shown that differently worded measures function well as parallel assessments of subjective health (Eriksson et al., 2001). Worth noting is that population studies often show that women experience their health as worse than men do (e.g., Taloyan, Leineweber, Hyde, \& Westerlund, 2015). Contrary to international findings, self-rated health (SRH) among the working population in Sweden was found to be worse for men than for women (Taloyan et al., 2015).

\section{Sleep Quality}

Around one-third of the general population in industrialized countries is reported to experience sleeping problems, while 6-10\% fulfil the DSM-IV criteria for insomnia (LeBlanc et al., 2009; Ohayon \& Bader, 2010; Walsh et al., 2011). Although it has been established that psychosocial factors at work impact sleep, much remains to be understood about the development of sleep disturbances in the working population (Linton et al., 2015). In a recent study, for example, higher work demands were shown to predict disturbed sleep (Åkerstedt et al., 2015). In addition, a reciprocal relationship has been shown between work characteristics and sleep disturbances (Törnroos et al., 2017; Åkerstedt et al., 2015). For Sweden, recent national statistics show that $5.3 \%$ of men and $10.4 \%$ of women report having had work-related sleep disorders during the past 12 months (Arbetsmiljöverket, 2016). For teachers in Sweden, gender differences are supported in a recent study by Arvidsson et al. (2016). 


\section{Health Complaints}

Although it is common in the adult working population to experience some degree of health complaints, self-report measures assessing such complaints may be fruitfully used to detect early signs of stress-related symptoms. In Sweden, a frequent reason for sick leave is currently Exhaustion Disorder (ED) (ICD-10 code: F43.8A). Exhaustion Disorder was classified by the Swedish National Board of Health and Welfare (NBHW) in 2003. It is characterized by physical and mental health symptoms (such as lack of energy, concentration problems, or minor aches and pains) experienced during two weeks prior to assessment (Socialstyrelsen, 2003). Furthermore, an overrepresentation of people on sick leave due to subjective health complaints, as represented by Exhaustion Disorder, has been found in female-dominated professions, such as education and health care (SBU, 2014).

\section{Working Conditions}

In Sweden, teachers represent a sector of the work force with unusual working conditions, as they have a 45-hour work week during the school terms, of which ten hours are allocated to be done at home. This way of organizing work has consequences for the separation between work and spare time, as well as for the possibilities to recover from work. Recent research on teachers in Sweden has indicated lack of recovery from work to be associated with higher incidence of burnout (Arvidsson et al., 2016). Besides the difficulty of separating work and spare time, due to the specific regulations controlling the working hours, the possibility of relaxing from work is also connected to the type of intellectual work teachers do, the intense work days they experience, as well as their emotional engagement with their students (Schad, 2019).

\section{Work Environment Indicators}

Work-environment-related constructs act as a strong predictor for job satisfaction among teachers (Schad, 2019a). In addition, employees' appraisals of work experiences, such as collegial interactions, their psychological evaluation of the content and processes of work, as well as their role in the organization, overall, are important for job satisfaction, well-being, and organizational outcomes (Judge, Thoresen, Bono, \& Patton, 2001). Skaalvik and Skaalvik (2009) have reported on job satisfaction being negatively associated with burnout. In this study, the relationship between well-being and several key characteristics in the work environment was assessed, which, in line with previous research, would influence teacher well-being (Dollard \& Bakker, 2010). Quantitative demands, a form of work overload, refers to high demands and few opportunities to take breaks (Byrne, 1999; Day et al., 2006) and have been shown to be of relevance for burnout and work engagement (Schaufeli, Bakker, \& Van Rhenen, 2009). Physical working conditions have been shown to be important predictors for teacher turnover (Loeb, Darling-Hammond, \& Luczak, 2005) and job satisfaction (Kloep \& Tarifa, 1994). Moreover, teachers' perception of role clarity was measured; it is defined in the literature as the degree to which an individual understands their job information and the performance 
expectations of their position (Rizzo, House, \& Lirtzman, 1970). This has been shown to be an especially important aspect of teaching (Miller, 2002). A deficient workplace communication climate and unsatisfactory communicative interactions with colleagues may be viewed as interpersonal stressors, unnecessarily depleting emotional and cognitive resources, most likely affecting teachers' job satisfaction, work performance, and engagement.

\section{Aim and Research Questions}

The aim of the present study was to build on previous research in our group by investigating teachers' perceptions of their health and working conditions. Specifically, the objectives of the present study were to:

1) assess teachers' perceptions of work-related health and working conditions;

2) examine the relationship among several key characteristics in teachers' work environment; and

3) examine the importance for well-being of job satisfaction, separation between work and spare time, and recovery from work.

\section{Method}

We assessed teachers' work-related health and working conditions with a comprehensive battery of health and work-related questions, and also the relationship between several key characteristics in teachers' work environment that would likely influence well-being. Due to the specific working conditions teachers experience in Sweden today, attention was also directed to separation between work and spare time, and recovery from work, and the relation of these two constructs to wellbeing and health complaints.

\section{Study Design}

In order to establish research collaboration, a broad call for interest was distributed through the development section of the Skåne Association of Local Authorities (Kommunförbundet Skåne), and the sampling method is therefore of a voluntary nature. In the interest of generalizability, a stratification was achieved as the sample was drawn from two municipalities different in socio-economic character. A cross-sectional survey was administered to all primary and lower secondary school teachers working in public schools in these municipalities in southern Sweden. The survey data was collected during October and November 2015 using an online survey tool (Webbenkater.com). Three reminders were distributed within a two-week period after the initial survey distribution.

The two municipalities consisted of a city with a population of around 50,000 and a suburban municipality with a population of around 35,000. Participation was voluntary and the participants were presented with an electronic informed consent document, which stated the purpose of the study and that individual responses would be kept confidential. 


\section{Participants}

All teachers $(N=744)$ working with pupils aged $6-16$ in public schools in the two municipalities were invited to participate in the study. The response rate was $61 \%$ $(N=455)$. In total, 401 teachers (216 from municipality 1 and 185 from municipality 2) were included in the study, as they met the inclusion criteria of working at least $50 \%$ of full time and having responded to at least $60 \%$ of the questions in the survey. The age of the participants ranged from 23 to 65 years, with a mean age of 46.2 years ( $S D=10.0$ years); $13.0 \%$ of the teachers were below 35 years of age, $49.9 \%$ were in the age span 35 to 49 , and $37.2 \%$ were older than 50 . The mean years of teaching experience was 17.3 years ( $S D=11.1$ years); $9.5 \%$ had $1-3$ years; $6.5 \%$ 4-6 years; $46.1 \%$ 7-18 years; $21.7 \% 19-30$ years; and $16.2 \%$ had 31 or more years of teaching experience. The average number of years employed at the present school was 8.9 ( $S D=8.4$ years), with $80 \%$ having worked at the present school two years or more. See Table 1 for further information on sociodemographic, lifestyle, and occupational factors.

Table 1

Sociodemographic and lifestyle factors and occupational factors in the total study population $(N=401)$, stratified by gender

\begin{tabular}{|c|c|c|c|c|c|c|}
\hline \multicolumn{2}{|l|}{ Dimensions } & \multicolumn{2}{|c|}{ All teachers } & \multirow{2}{*}{$\begin{array}{c}\text { Females } \\
N=305\end{array}$} & \multicolumn{2}{|l|}{ Males } \\
\hline Sociodemographic and lifestyle factors & Scale & & $N=401$ & & $N=91$ & $P^{*}$ \\
\hline Age, years; mean $(S D)$ & & 401 & $46.2(10.0)$ & $46(10)$ & $46(11)$ & $.340^{\mathrm{a}}$ \\
\hline Country of birth & & 401 & & & & $.345^{\mathrm{b}}$ \\
\hline Born in Sweden, $n(\%)$ & & & $369(92)$ & $279(91)$ & $86(95)$ & \\
\hline Outside Sweden, $n(\%)$ & & & $32(8)$ & $26(9)$ & $5(5)$ & \\
\hline Marital status & & 401 & & & & \\
\hline Married or living together, $n(\%)$ & & & $340(85)$ & $261(86)$ & $74(81)$ & $.324^{\mathrm{b}}$ \\
\hline Single, $n(\%)$ & & & $61(15)$ & $44(14)$ & $17(19)$ & \\
\hline Children residing at home & & 401 & & & & $.984^{\mathrm{b}}$ \\
\hline Yes, $n(\%)$ & & & $234(58)$ & $178(58)$ & $53(58)$ & \\
\hline No, $n(\%)$ & & & $167(42)$ & $127(42)$ & $38(42)$ & \\
\hline Well-being; mean $(S D)$ & $0-100$ & 396 & $55.0(21.5)$ & $54.7(21.6)$ & $56.6(21.1)$ & $.462^{\mathrm{a}}$ \\
\hline $\begin{array}{l}\text { Physical activity ( }<3.5 \text { hour/week), } \\
n(\%)\end{array}$ & & 401 & $174(44)$ & $133(44)$ & $39(43)$ & $.609^{\mathrm{a}}$ \\
\hline $\begin{array}{l}\text { Self-rated health, mean }(S D) \\
(0,25,50,75,100)\end{array}$ & $0-100$ & 397 & $58.5(21.1)$ & $58.1(21.4)$ & $59.6(20.3)$ & $.659^{\mathrm{a}}$ \\
\hline Sleep quality, mean $(S D)$ & $1-4^{c}$ & 398 & $2.2(0.9)$ & $2.2(0.9)$ & $2.2(.8)$ & $.871^{\mathrm{a}}$ \\
\hline $\begin{array}{l}\text { Health complaints, during the last } \\
\text { month }\left({ }^{3} 3\right), n(\%)\end{array}$ & $1-4^{\mathrm{c}}$ & 397 & & & & \\
\hline $\begin{array}{l}\text { Heart palpitations and discomfort } \\
\text { (e.g., chest pressure) }\end{array}$ & & & $50(12)$ & $37(12)$ & $12(13)$ & $.646^{\mathrm{a}}$ \\
\hline Sensitivity to light and noise & & & $163(41)$ & $133(44)$ & $29(32)$ & $.013^{\mathrm{a}}$ \\
\hline
\end{tabular}




\begin{tabular}{|c|c|c|c|c|c|c|}
\hline Impaired short-term memory & & & $148(37)$ & $119(40)$ & $27(30)$ & $.011^{\mathrm{a}}$ \\
\hline Impaired concentration or confusion & & & $124(31)$ & $102(34)$ & $21(23)$ & $.054^{\mathrm{a}}$ \\
\hline Dizziness, anxiety, or worry & & & $79(20)$ & $59(20)$ & $18(29)$ & $.392^{\mathrm{a}}$ \\
\hline $\begin{array}{l}\text { Severe fatigue/lack of energy, even after } \\
\text { resting }\end{array}$ & & & $116(29)$ & $90(30)$ & $22(24)$ & $.238^{\mathrm{a}}$ \\
\hline Impatience & & & $103(26)$ & $78(26)$ & $22(24)$ & $.227^{\mathrm{a}}$ \\
\hline $\begin{array}{l}\text { Losing your temper (becoming irritated, } \\
\text { over small things }\end{array}$ & & & $88(22)$ & $67(22)$ & $20(22)$ & $.472^{\mathrm{a}}$ \\
\hline Easily offended (e.g., close to tears) & & & $66(17)$ & $61(20)$ & $5(6)$ & $<.001^{\mathrm{a}}$ \\
\hline $\begin{array}{l}\text { Feelings of hopelessness or powerless- } \\
\text { ness }\end{array}$ & & & $86(22)$ & $67(22)$ & $17(19)$ & $.219^{\mathrm{a}}$ \\
\hline Not able to take initiative & & & $62(16)$ & $47(19)$ & $15(16)$ & $.648^{\mathrm{a}}$ \\
\hline $\begin{array}{l}\text { Separation between work and spare } \\
\text { time, mean }(S D)\end{array}$ & $1-4$ & & $2.4(($ & $2.4(0.8)$ & $2.4(0.8)$ & $.614^{\mathrm{a}}$ \\
\hline Recovery from work $\left.{ }^{3} 3\right), n(\%)$ & & 398 & $134(34)$ & $108(34)$ & $25(28)$ & $.216^{\mathrm{a}}$ \\
\hline Estimation of work ability, mean $(S D)$ & $1-3$ & 397 & $2.8(0.5)$ & $2.8(0.5)$ & $2.7(0.5)$ & $.254^{\mathrm{a}}$ \\
\hline \multicolumn{7}{|l|}{ Occupational factors } \\
\hline Seniority, years; mean $(S D)$ & & 401 & $17.3(11.1)$ & $17.5(11.1)$ & $17.0(11.4)$ & $.585^{\mathrm{a}}$ \\
\hline Present employer, years; mean $(S D)$ & & 401 & $8.9(8.5)$ & $8.7(8.3)$ & $9.6(9.2)$ & $.403^{\mathrm{a}}$ \\
\hline Type of employment, $n(\%)$ & & 401 & & & & $.137^{\mathrm{b}}$ \\
\hline Permanent & & & $374(93.3)$ & $281(92.1)$ & $88(96.7)$ & \\
\hline Temporary & & & $16(4.0)$ & $15(4.9)$ & $1(1.1)$ & \\
\hline Substitute & & & $2(0.5)$ & $2(0.7)$ & - & \\
\hline Other & & & $9(2.2)$ & $7(2.3)$ & $2(2.2)$ & \\
\hline School years taught, $n(\%)$ & & 401 & & & & $.057^{\mathrm{b}}$ \\
\hline F-6 (6-12-year-olds) & & & $215(53.6)$ & $172(56.4)$ & $41(45.1)$ & \\
\hline 7-9 (13-15-year-olds) & & & $186(46.4)$ & $133(43.6)$ & $50(54.9)$ & \\
\hline Hours worked, $n(\%)$ & & 401 & & & & $.005^{\mathrm{b}}$ \\
\hline 51 to $80 \%$ & & & $48(12.0)$ & $41(13.4)$ & $6(6.6)$ & \\
\hline 81 to $99 \%$ & & & $29(7.2)$ & $27(8.9)$ & $2(2.2)$ & \\
\hline Full-time & & & $324(80.8)$ & $237(77.7)$ & $83(91.2)$ & \\
\hline Team leader, $n(\%)$ & & 401 & $49(12.2)$ & $39(12.8)$ & $10(11.0)$ & $.648^{\mathrm{b}}$ \\
\hline Coordinator, $n(\%)$ & & 401 & $23(5.7)$ & $17(5.6)$ & $6(6.6)$ & $.715^{\mathrm{b}}$ \\
\hline Head teacher, $n(\%)$ & & 401 & $44(11.0)$ & $36(11.8)$ & $8(8.8)$ & $.423^{\mathrm{b}}$ \\
\hline $\begin{array}{l}\text { Does your position correspond to } \\
\text { your training? } n(\%)\end{array}$ & & 401 & & & & $.020^{\mathrm{b}}$ \\
\hline Yes, completely & & & $277(69.1)$ & $213(69.8)$ & $60(65.9)$ & \\
\hline Yes, partly & & & $110(27.4)$ & $83(27.2)$ & $26(28.6)$ & \\
\hline No & & & $14(3.5)$ & $9(3.0)$ & $5(5.5)$ & \\
\hline Quantitative demands; mean $(S D)$ & $(0-5)^{\mathrm{c}}$ & 401 & $3.41(0.67)$ & $3.45(0.68)$ & $3.31(0.64)$ & $.025^{\mathrm{a}}$ \\
\hline
\end{tabular}

Note: ${ }^{a}$ Mann-Whitney $U$ test, ${ }^{b}$ Chi-square ${ }^{c}$ Higher scores indicate a less favorable situation. ${ }^{*} n=396$ 


\section{Ethical Considerations}

The study protocol was approved by the Regional Ethical Review Board in Lund, Sweden (reg. nr 2014/654). Participation was voluntary and the participants were first presented with an electronic informed consent document, which stated the purpose of the study and that individual response on the measures would be kept confidential.

\section{Measures}

Information was collected on personal demographic variables including gender, age, marital status, whether there are children residing at home, and whether the respondent was born in Sweden. Questions regarding the participants' occupational situation covered employment status, working hours, years of work experience, years employed at current school, and grade levels taught. In addition, a question was asked regarding the match between teaching duties and teaching qualifications. The respondents were also asked if they held a position as team leader, coordinator, or head teacher (Förstelärare) (Table 1).

\section{Subjective Well-Being}

Subjective well-being was assessed with the 5-item World Health Organization Well-Being Index (WHO-5), which measures recently experienced mood (e.g., Over the last two weeks, I have felt cheerful and in good spirits) (Bech, Olsen, Kjoller, \& Rasmussen, 2003). The items were rated on a 6-point scale (response alternatives: $0=$ never to $5=$ all the time) and the total sum was multiplied by 4 to gain a score between 0 and 100. Regarding internal consistency, an alpha value of .82 has previously been reported, and the scale has shown strong associations with comprehensive well-being scales (Topp et al., 2015).

\section{Physical Activity}

Physical activity (moderately strenuous activities) was assessed with one question from the Swedish National Public Health study on health, lifestyle, and living conditions. The purpose the survey is to monitor changes in health over time in the Swedish population, and it constitutes part of the public health policy (Folkhälsomyndigheten, 2016). It has been conducted annually since 2004 and comprises a random sample of ca. 20,000 individuals aged 16-84, reporting on the state of their health. (How much time, during an ordinary week, do you spend on moderately effortful activities that make you warm, such as brisk walks, gardening, heavy housework, biking, swimming? This could vary over the year, but try to estimate an average: $1=$ none at all, $2=$ at most one hour per week, $3=$ between one and three hours per week, $4=$ more than three, but less than five hours per week, $5=$ five hours per week or more.) The objective was to assess how large a proportion of the sample achieved at least 3 hours/week of physical activity.

\section{Self-Rated Health}

Self-rated health was assessed with one item from the Copenhagen Psychosocial Questionnaire II (COPSOQ-II) (Kristensen, Hannerz, Høgh, \& Borg, 2005). (In 
general, would you say your health is: $0=$ poor, $25=$ fair, $50=$ good, $75=$ very good, $100=$ excellent.)

Sleep Quality, Health Complaints, and Separation Between Work and Spare Time

Sleep quality ( 3 items), health complaints (11 symptoms), and separation between work and spare time (4 items) were assessed using the Lund University Checklist for Incipient Exhaustion (LUCIE) (Karlson et al., 2010). This self-report measure was developed to detect early signs of stress-related symptoms. Answers on sleep quality and health complaints were given on a 4-point scale, ranging from $1=n o t$ at all to $4=$ very often (e.g., I have had trouble falling asleep). Answers on separation between work and spare time were given on a 4-point scale, ranging from $4=$ not at all to $1=$ very often (e.g., Problems at work make me irritable at home.)

\section{Recovery from Work}

Recovery from work was assessed with one question (Arbetsmiljöverket, 2014a). (Besides sleep, do you get enough recovery between work days?) Answers were given on a 5 -point scale, ranging from $1=$ far from enough to $5=y e s$, definitely.

\section{Estimation of Work Ability and Sick Leave}

Estimation of work ability was assessed with one question from the Work Ability Index (WAI) (Toumi, Illmarinen, Jahkola, Katajarinne, \& Tulkki, 1998). The question was slightly modified to better reflect the teaching profession. (Do you believe, according to your present state of health, that you will be able to work as a teacher two years from now? $1=$ no, $I$ don't think so, $2=I$ am uncertain, and $3=y e s$, probably.) Sick leave was assessed with one item from the same index. (How many days have you been away from work due to illness or injury (care, treatment, or examination) during the last year (12 months)? $5=$ none, $4=1-7$ days, $3=8-24$ days, $2=25-99$ days, and $1=100-365$ days.)

\section{Work Environment Indicators}

Job satisfaction was assessed with a modified and expanded 5-item scale, building on items from the Copenhagen Psychosocial Questionnaire II (COPSOQ-II) (Kristensen et al., 2005). The items were adjusted to fit the teaching profession (e.g., Regarding your work in general, how pleased are you with your work prospects as a teacher?). Answers were given on a 4 -point scale: $1=$ very dissatisfied to $4=$ very satisfied.

Quantitative work demands were assessed with a 4-item subscale from COPSOQ-II (Kristensen et al., 2005) (e.g., Do you fall behind in your work?). Answers were given on a 6-point scale ranging from $0=$ never to $5=$ almost always.

Physical work environment was assessed with a subscale from the school version of a Swedish questionnaire developed by Andersson (1998). The scale contains 4 items (e.g., How do you perceive the school environment at large, regarding work environment as far as access to computers goes?). Answers were given on a 5-point scale, ranging from $1=$ very poor to $5=$ very good. 
Role clarity was assessed with a Swedish version (Schad, 2019a) of a 6-item scale originally developed by Rizzo et al. (1970) (e.g., Clear, planned goals exist for $m y$ job). Answers were given on a 4-point scale ranging from $1=$ does not fit at all to $4=$ fits perfectly.

Collegial communication was assessed with 6 items drawn from a scale originally developed by Cortina, Magley, Williams, and Langhout (2001) (e.g., I am treated with respect). Answers were given on a 5-point scale: $0=n e v e r$, to $4=$ for the most part.

Workplace communication climate was assessed with 6 items (Schad, 2019a) (e.g., People are keen on expressing their ideas). Answers were given on a 4-point scale: $1=$ does not fit at all, to $4=$ fits perfectly.

\section{Statistical Analysis}

Means, standard deviations, and Cronbach's alpha coefficients were used to describe the study variables. Teachers working in the two municipalities reported similar mean scores on sociodemographic and lifestyle factors and were therefore treated as one sample (data not reported). The statistical computations were performed with IBM SPSS Statistics 24.0 and SPSS AMOS 24 for Windows (IBM Corp. Released 2016). Cronbach's alpha coefficients $(\alpha)$ were used to assess the internal consistency of the variables. As recommended by Hoaglin and Iglewicz (1987), all variables were inspected for outliers and data recoding was used in the case of the variable "job satisfaction", where a few extreme outliers were found.

Two-tailed actual $p$-values are reported where appropriate. Spearman correlations were used to explore associations between continuous study variables. Point biserial correlations were used to estimate the association between binary variables and continuous variables. Group comparisons were done with Pearson's Chi-square test, Mann-Whitney $U$ tests, and independent-samples $t$-test.

In addition, a theoretically driven regression using PROCESS, model 4 (Hayes, 2013), was performed to assess whether separation between work and spare time, and recovery from work, mediate the association between, respectively, job satisfaction, well-being, and health complaints. The PROCESS macro allows for calculation of direct, indirect and total effects, utilizing bootstrapping (5,000 samples) to calculate standard errors (SE) and confidence intervals (CI).

The WHO-5 was dichotomized into good and poor subjective health following recommendations by Topp et al. (2015). The WHO-5 variable was also used as a continuous outcome in correlation and regression analysis.

\section{Results}

\section{Characteristics of the Study Population}

The study population comprised $76.1 \%$ women. There was no significant difference between men and women regarding the mean scores for sociodemographic factors (see Table 1). There was also no significant difference between women and men regarding physical activity, self-rated health, sleep quality, separation between work and spare time, recovery from work, and estimation of work ability. Women, 


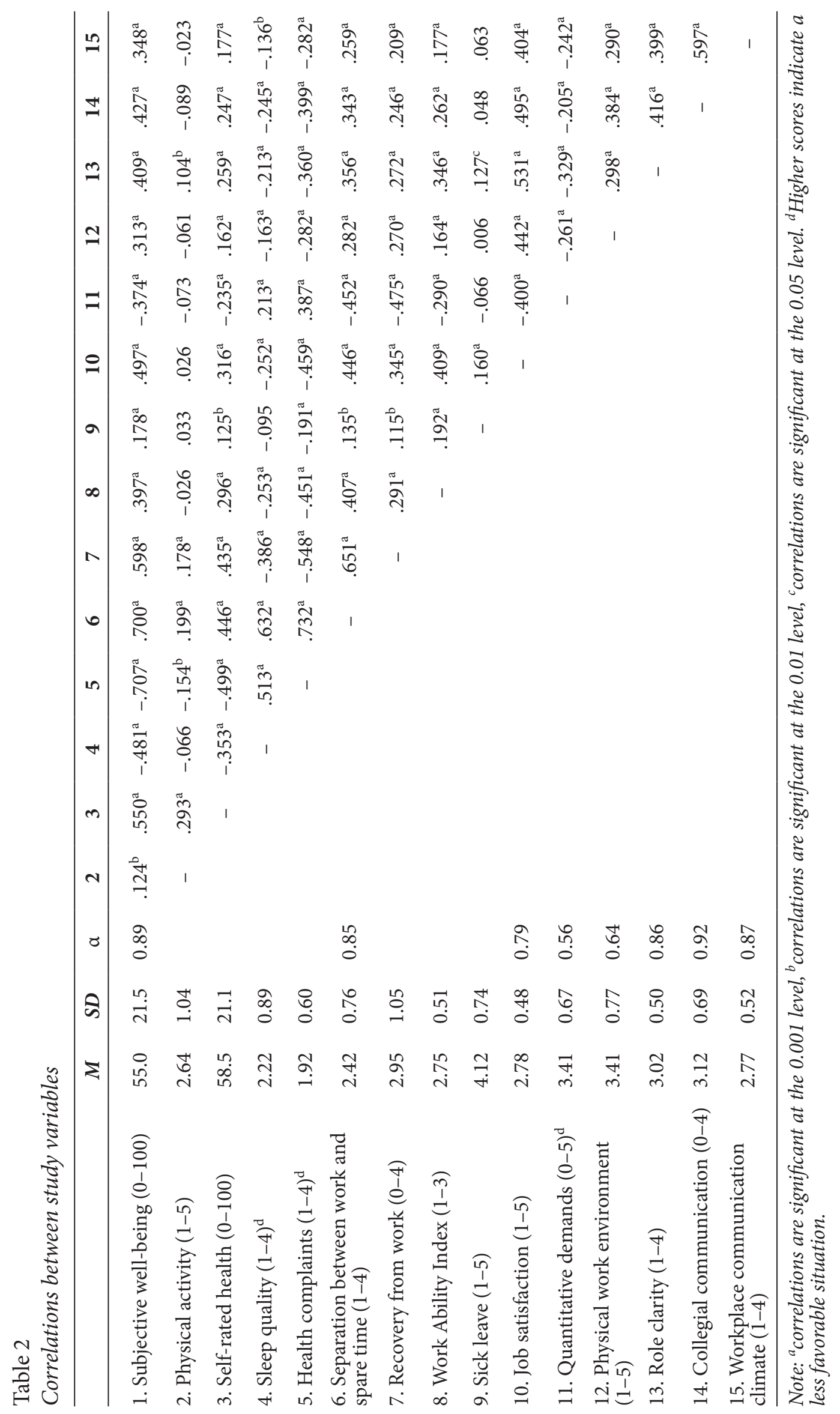


however, reported significantly more problems on 3 of 11 health complaints (sensitivity to light and noise, impaired short-term memory, and being easily offended).

Regarding the occupational factors, women to a larger extent teach younger children, work part-time, and have a position corresponding to their training. Women also reported higher scores on quantitative demands.

\section{Descriptive Statistics}

\section{Subjective Well-Being}

The mean score for the well-being scale was $55.0(S D=21.5)$, mean (women) $=54.8$, $S D=21.6$, mean $(\mathrm{men})=56.4, S D=21.2$. In this sample of 401 teachers, $40.2 \%$ scored below or equal to the cut-off of 50 recommended in the screening for depression (Topp et al., 2015); 19.9\% had a score below or equal to 32, the cut-off for minor depression; and $6.6 \%$ had a score below or equal to 20 , the cut-off for major depression (Topp et al., 2015).

\section{Physical Activity}

Physical activity was reported to have the following distribution: not at all, 2.0\%, at most 1 hour/week, 11.8\%, between 1 and 3 hours/week, 30.0\%, more than 3 hours but less than 5 hours/week, 32.0\%, and 5 hours/week or more, 24.2\%. Dichotomizing the results, $43.8 \%$ qualify as leading a sedentary lifestyle (> 3 hours/week) (Folkhälsomyndigheten, 2016).

\section{Self-Rated Health}

Self-rated health was assessed with one question generating the following distribution: excellent (7.8\%), very good (33.2\%), good (45.6\%), less good (11.8\%), and poor (1.5\%); for mean value and standard deviation, see Table 1.

\section{Sleep Quality and Health Complaints}

Sleep quality during the last month was assessed with three questions combined into a single variable. On an item level, almost half of the respondents (48.8\%) reported being in agreement or strong agreement with waking up several times or having disturbed sleep and $44.5 \%$ reported being in agreement that they woke up early in the morning and had trouble falling back asleep, while over one third (32.1\%) reported that they had trouble falling asleep. An average of 1.25 symptoms with disturbed sleep were reported/person $(S D=1.22)$. One or more symptoms of sleeping problems were reported by $61.0 \%$ ( 1 symptom $16.1 \%$, 2 symptoms $19.6 \%$, and 3 symptoms $23.4 \%$ ). Although no gender or age differences were found on the full scale level, a trend was found indicating that for men problems with maintaining sleep and/or feeling restored when awakening increased somewhat with age $\left(\mathrm{T}_{\mathrm{JT}}=1,832.50, \mathrm{z}=2.151, p=-.032\right)$.

In this study, $70.1 \%$ reported health complaints during the last month on at least one item. An average of 2.7 health complaints $(S D=2.9)$ per person were reported, with sensitivity to noise (41\%), impaired short-term memory (37\%), and impaired concentration or confusion (31\%) being the most prevalent health complaints (see Table 2). 


\section{Separation Between Work and Spare Time}

Separation between work and spare time was assessed with four questions combined into a single variable (see Table 2). On an item level, $65.1 \%$ reported being in agreement or strong agreement that work consumes so much energy that I lose the strength to take care of things I have to do at home; 53.2\% that I have trouble relaxing during my spare time due to constant thoughts about work, while $45.0 \%$ reported that problems at work make me irritable at home, and $38.7 \%$ that I have trouble sleeping due to constant worries about work.

\section{Recovery from Work}

Regarding whether the participants felt that they had the possibility to recover from work, the distribution of responses was: yes, definitely (5.3\%), yes, mostly (27.1\%), no, somewhat unsatisfactory (33.9\%), no, quite unsatisfactory (24.4\%), and no, far from satisfactory (9.3\%).

\section{Estimation of Work Ability and Sick Leave}

Regarding estimation of work ability, $78.1 \%$ reported that they, taking their health into account, would still be able to work as teachers two years from now, $18.6 \%$ were unsure, and $3.3 \%$ thought they could not.

Absenteeism due to sickness or injury during the last 12 months was also assessed, and generated the following distribution: no absence (30.0\%); 1-7 days (55.2\%); 8-24 days (11.8\%); 25-99 days (2.5\%); and 100-365 days (0.5\%).

\section{Well-Being in Relation to Sociodemographic,} Lifestyle, and Occupational Factors

Sociodemographic factors (gender, age, country of birth, marital status, and children residing at home) and lifestyle factors (physical exercise) showed no relation to well-being. Neither did most occupational factors (type of employment, hours worked, position corresponding with training, position as team leader, coordinator, or head teacher). Health-related factors such as self-rated health, sleep quality, and health complaints (Table 3 ) all proved to be related to well-being.

Spearman rank order correlation of the study variables (Table 2) showed high correlations of well-being with self-rated health $\left(r_{s}=.550\right)$, health complaints $\left(r_{s}=-.707\right)$, separation between work and spare time $\left(r_{s}=.700\right)$, and recovery from work $\left(r_{s}=.589\right)$. Increasing levels of well-being were positively associated with increasing levels of physical work environment, role clarity, collegial communication, and workplace communication climate (ranging from $r_{s}=.313$ to $r_{s}=.427$ ), while increasing levels of well-being were negatively associated with quantitative demands $\left(r_{s}=-.374\right)$.

\section{Multivariate Analysis}

In order to further elucidate the relationship among the work-related health variables, a series of multivariate analyses were performed, centered on relevant health variables (well-being and health complaints) and job satisfaction, using the macro 
PROCESS, model 4 (Hayes, 2013). First, it was tested whether separation between work and spare time and recovery from work would mediate the relationship between job satisfaction and well-being. The results show (Figure 1) that the indirect paths from job satisfaction to separation between work and spare time $(b=.72$, $S E=.07, p<.001)$ and recovery from work $(b=.77, S E=.10, p<.001)$ were both significant. Also, the indirect paths from separation between work and spare time $(b=.59, S E=.07, p<.001)$ and recovery from work $(b=.26, S E=.045, p<.001)$ to well-being were significant. Both independent paths between job satisfaction and well-being are thus significant, indicating mediation. The direct path from job satisfaction to well-being remained significant, indicating only partial mediation $(b=.53, S E=.09, p<.001)$.

The bootstrapping for indirect effects showed that the total indirect effect $(.622$ $C I[.491, .767])$ as well as the indirect effect through separation between work and spare time $(.426 C I[.311, .557])$ and recovery from work $(.197 C I[.123, .291])$ were significant. The overall model explained $55.8 \%$ of the variance in well-being, while supporting partial mediation of job satisfaction by separation between work and spare time, and by recovery from work.

Secondly, it was tested whether separation between work and spare time and recovery from work would mediate the relationship between job satisfaction and health complaints. The direct path from job satisfaction to health complaints remained significant $(b=-0.22, S E=.07, p<.001)$, indicating only partial mediation. Also, the paths from separation between work and spare time, and recovery from work $(b=-0.07, S E=.02, p=.006)$, to health complaints were significant (Figure 2).

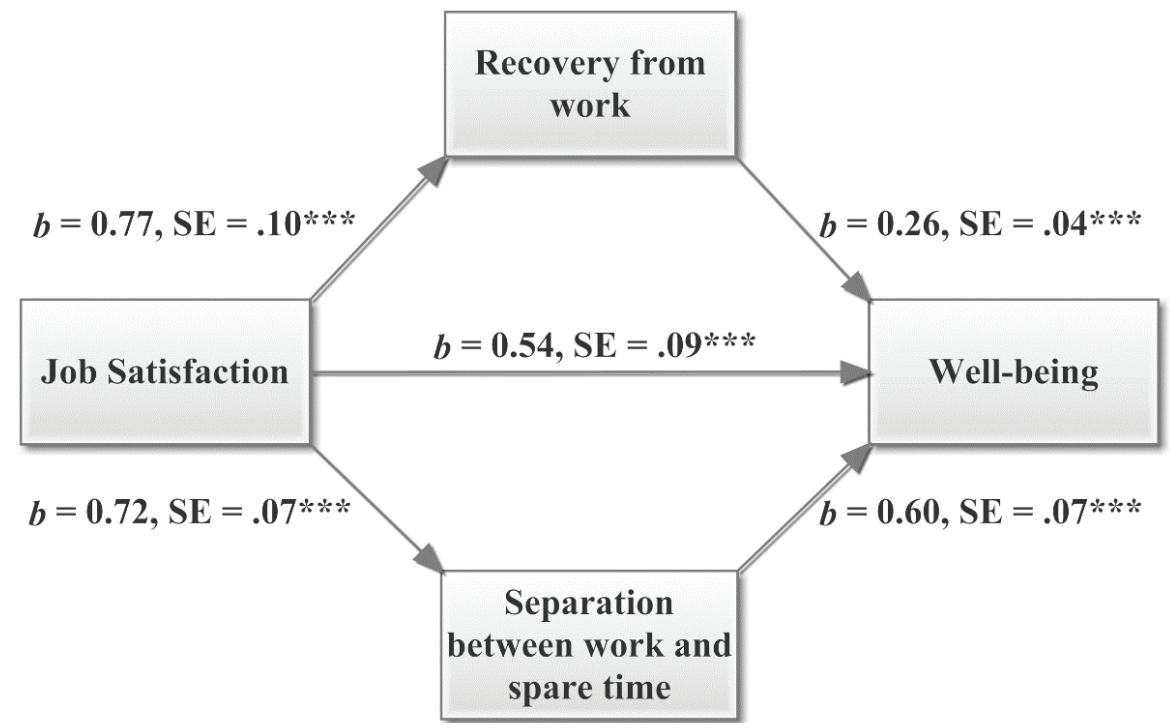

Figure 1. Coefficients for the indirect and direct paths of the mediation analysis with well-being as outcome variable $\left.{ }^{* * *} p<.001\right)$.

The bootstrapping for indirect effects showed that the total indirect effect $(-.369$ CI $[-.452,-.296])$ as well as the indirect effect through separation between work and spare time $(-.316 C I[-.397,-.257])$ and recovery from work $(-.054 C I$ 
Table 3

Subjective well-being (WHO-5) dichotomized into: poor (0-50) and good (51-100) (N=396)

\begin{tabular}{|c|c|c|c|c|}
\hline \multirow[b]{2}{*}{ Dimensions } & \multirow[b]{2}{*}{ Scale } & \multirow{2}{*}{$\begin{array}{l}\text { Poor } \\
N=157\end{array}$} & \multirow{2}{*}{$\begin{array}{c}\text { Good } \\
N=239\end{array}$} & \multirow[b]{2}{*}{$\boldsymbol{P}^{*}$} \\
\hline & & & & \\
\hline \multicolumn{5}{|l|}{ Sociodemographic and lifestyle factors } \\
\hline Physical activity, mean $(S D)$ & $1-5$ & $2.53(1.03)$ & $2.72(1.04)$ & $.069^{\mathrm{b}}$ \\
\hline Self-rated health, mean $(S D)$ & $0-100$ & $46.8(19.8)$ & $\begin{array}{c}66.4 \\
(18.1)\end{array}$ & $<.001^{\mathrm{b}}$ \\
\hline Sleep quality, mean $(S D)$ & $1-4^{\mathrm{a}}$ & $2.6(0.9)$ & $1.9(0.8)$ & $<.001^{\mathrm{b}}$ \\
\hline Health complaints, during the last month $\left({ }^{3} 3\right)$ & $1-4^{\mathrm{a}}$ & & & \\
\hline \multicolumn{2}{|c|}{ Heart palpitations and discomfort (e.g., chest pressure), $n$ (\%) } & $32(20.1)$ & $18(7.6)$ & $<.001^{\mathrm{b}}$ \\
\hline \multicolumn{2}{|l|}{ Sensitivity to light and noise, $n(\%)$} & $84(52.8)$ & $78(32.9)$ & $<.001^{\mathrm{b}}$ \\
\hline \multicolumn{2}{|l|}{ Impaired short-term memory, $n(\%)$} & $92(57.9)$ & $55(23.2)$ & $<.001^{\mathrm{b}}$ \\
\hline \multicolumn{2}{|l|}{ Impaired concentration or confusion, $n(\%)$} & $85(53.5)$ & $38(16.0)$ & $<.001^{\mathrm{b}}$ \\
\hline \multicolumn{2}{|l|}{ Dizziness, anxiety, or worry; $n(\%)$} & $60(37.5)$ & $19(8.0)$ & $<.001^{\mathrm{b}}$ \\
\hline \multicolumn{2}{|l|}{ Severe fatigue/lack of energy, even after resting, $n(\%)$} & $91(57.2)$ & $25(10.5)$ & $<.001^{\mathrm{b}}$ \\
\hline \multicolumn{2}{|l|}{ Impatience, $n(\%)$} & $73(45.9)$ & $29(12.2)$ & $<.001^{\mathrm{b}}$ \\
\hline \multicolumn{2}{|c|}{ Losing your temper (becoming irritated) over small things, $n$ (\%) } & $64(40.3)$ & $24(10.1)$ & $<.001^{\mathrm{b}}$ \\
\hline \multicolumn{2}{|l|}{ Easily offended (e.g., close to tears), $n$ (\%) } & $51(32.1)$ & $15(6.3)$ & $<.001^{\mathrm{b}}$ \\
\hline \multicolumn{2}{|l|}{ Feelings of hopelessness or powerlessness, $n(\%)$} & $69(43.4)$ & $16(6.8)$ & $<.001^{\mathrm{b}}$ \\
\hline \multicolumn{2}{|l|}{ Not able to take initiative, $n(\%)$} & $50(31.4$ & $12(5.1)$ & $<.001^{\mathrm{b}}$ \\
\hline Separation between work and spare time, mean $(S D)$ & $1-4$ & $2.9(0.53)$ & $2.1(0.7)$ & $<.001^{\mathrm{b}}$ \\
\hline Recovery from work $\left({ }^{3} 3\right), n(\%)$ & $0-4$ & $93(58.5)$ & $40(16.9)$ & $<.001^{\mathrm{b}}$ \\
\hline Estimation of work ability, mean $(S D)$ & $1-3$ & $2.57(0.57)$ & $2.87(0.42)$ & $<.001^{\mathrm{b}}$ \\
\hline Sick leave, mean $(S D)$ & $1-5$ & $3.96(0.75)$ & $4.22(0.72)$ & $.001^{\mathrm{b}}$ \\
\hline \multicolumn{5}{|l|}{ actors } \\
\hline \multicolumn{2}{|l|}{ Seniority, years worked; mean $(S D)$} & $15.5(9.7)$ & $\begin{array}{c}18.5 \\
(11.9)\end{array}$ & $.051^{\mathrm{b}}$ \\
\hline \multicolumn{2}{|l|}{ Present employer, years; mean $(S D)$} & $7.8(7.8)$ & $9.6(8.8)$ & $.049^{\mathrm{b}}$ \\
\hline \multicolumn{2}{|l|}{ School years taught } & & & $.180^{\mathrm{c}}$ \\
\hline \multicolumn{2}{|l|}{ F-6 (6-12 year-olds), $n(\%)$} & $76(50.7)$ & $130(59.6)$ & \\
\hline \multicolumn{2}{|l|}{ 7-9 (13-15 year-olds), $n(\%)$} & $74(49.3)$ & $88(40.4)$ & \\
\hline Job satisfaction, mean $(S D)$ & $1-4$ & $2.5(0.5)$ & $2.9(0.4)$ & $<.001^{\mathrm{b}}$ \\
\hline Quantitative demands, mean $(S D)$ & $0-5^{\mathrm{a}}$ & $3.7(0.6)$ & $3.2(0.7)$ & $<.001^{\mathrm{b}}$ \\
\hline Physical work environment, mean $(S D)$ & $1-5$ & $2.8(0.7)$ & $2.4(0.8)$ & $<.001^{\mathrm{b}}$ \\
\hline Role clarity, mean $(S D)$ & $1-4$ & $2.8(0.5)$ & $3.1(0.5)$ & $<.001^{\mathrm{b}}$ \\
\hline Collegial communication, mean $(S D)$ & $0-4$ & $2.8(0.7)$ & $3.3(0.6)$ & $<.001^{\mathrm{b}}$ \\
\hline Workplace communication climate, mean $(S D)$ & $1-4$ & $2.6(0.5)$ & $2.9(0.5)$ & $<.001^{\mathrm{b}}$ \\
\hline
\end{tabular}

Note: ${ }^{a}$ Higher scores indicate a less favorable situation. ${ }^{b}$ Mann-Whitney $U$ test, ${ }^{c}$ Chi-Square test of independence (2-tailed). 
$[-.103,-.015])$ were significant. The overall model explained $55.7 \%$ of the variance in health complaints, while supporting mediation of job satisfaction, by separation between work and spare time, and recovery from work.

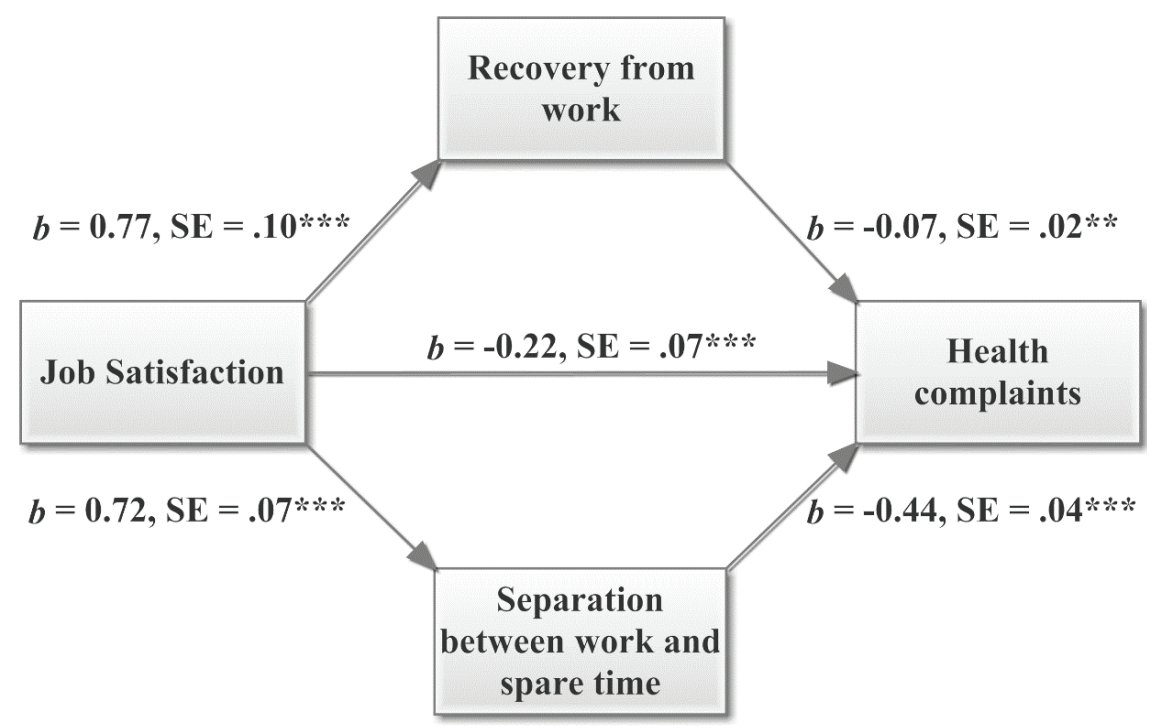

Figure 2. Coefficients for the indirect and direct paths of the mediation analysis with health complaints as outcome variable $\left({ }^{* * *} \mathrm{p}<.001,{ }^{* *} \mathrm{p}<.01\right)$.

\section{Discussion}

This study reports on teachers' work-related health and working conditions, as well as the relationship between well-being and several key characteristics in teachers' work environment. The results give evidence of a moderate relationship between well-being and quantitative demands, role clarity, physical work environment, as well as collegial and workplace communication. There is moderate support for the two models used to analyze the importance of separation between work and spare time, as well as recovery from work, respectively, for the association between job satisfaction and the outcome variables - well-being and health complaints.

\section{Subjective Well-Being}

In this study, $40.2 \%$ of the teachers reported below the cut-off score of 50 recommended in the screening for depression $(6.6 \%$ had a score below or equal to 20 , which is used as a cut-off for major depression; $19.9 \%$ had a score below or equal to 32, which is used as a cut-off for minor depression) (Topp et al., 2015). Compared to results from the Eurofond Quality of Life survey, teachers in our study scored well below the mean for the Swedish working population (64.1) (Eurofond, 2013). Sisask et al. (2014), however, have reported on teachers' wellbeing in a large study sampling 158 randomly selected schools throughout Europe, using WHO-5, to be on average 51.2, thus slightly lower but in line with our results. 


\section{Physical Activity}

An alarming $44 \%$ of the teachers in this study qualify as leading a sedentary lifestyle, as they indicated that they spend three hours or less per week exercising or performing fairly strenuous physical activities. Compared to national statistics regarding those with a post-secondary degree, this figure is almost twice as high (Folkhälsomyndigheten, 2016). Yet, from a European perspective, Sweden is among those countries where physical activity is comparatively low, as shown in a recent review by Loyen et al. (2016).

\section{Self-Rated Health}

The teachers in this study rated their general health well below the reference value for the working population (COPSOQ reference value for self-rated health $=66.0$ ). In addition, no gender differences or declining self-rated health with age were observed in our study, contrary to results from the European ETUCE study $(N=5461)$ (Nübling, Vomstein, Haug, Nübling, \& Adiwidjaja, 2011) and in a national health survey assessing 9,340 persons in Sweden (Folkhälsomyndigheten, 2016). Of interest are, in addition, results from two recent studies in Sweden assessing social workers $(N=723)$ and dental nurses $(N=616)$ (Nyqvist, Arnrup, \& Berthelsen, 2016). Both studies report that the self-rated health is below the COPSOQ reference value, with an average value of 61.0 for dental nurses and 57.4 for social workers.

The absence of gender and age differences in this study are surprising and should be viewed in light of the fact that Sweden has high gender equality, while still having a gender-segregated labor market. University educated workers have been found to have a more equal division of tasks in the home, such as child-care and domestic work. For example, in a Swedish study by Molarius et al. (Molarius, Granström, Lindén-Boström, \& Elo, 2014), domestic work was found to be a risk factor comparable to other major risk factors that correlate with self-rated ill-health in the population. Molarius found the PAR value (Population attributable risk) (Kleinbaum, Kupper, \& Morgenstern, 1982) to be $21 \%$ for women and $12 \%$ for men. This could possibly explain the lack of gender differences in self-rated health for teachers as a group.

\section{Sleep Quality}

Core nocturnal diagnostic criteria for insomnia include problems with initiating sleep, maintaining sleep, and/or feeling restored when awakening. Given that around $30 \%$ of the adult population suffers one or more of these criteria of insomnia (Roth, 2007), the results showing a rate of insomnia symptoms (one or more symptoms of sleeping problems) of $61 \%$ is indeed troublesome. In the research literature, it is often reported that women have higher incidence rates of insomnia than men, and that insomnia increases with age for women (Johnson, 2006). It is worth noting that no gender or age differences were found in this study regarding the prevalence of insomnia symptoms. The results in this study, therefore, support a trend observed by Nordin et al. (2013) indicating that younger women have higher incident rates of insomnia than previously found, thus leveling out any generational differences. For men, an increase with age of problems with maintaining sleep and/or feeling restored when awakening is found. 


\section{Health Complaints}

Sensitivity to noise, impaired short-term memory, impaired concentration or confusion were common health complaints among the teachers in this study. These symptoms were also reported as more problematic among women than among men. Regarding sensitivity to noise, the results are in line with national statistics reporting on noise-related occupational problems as common in the educational sector (Lärarnas Riksförbund, 2013). While this is an under-researched area, a recent study by Fredriksson et al. (2016) reported that women working as pre-school teachers have an increased risk of hearing-related disorders.

Taken together, the results are in line with previous research indicating teachers in Sweden to be highly affected by exhaustion, as measured in the Maslach Burnout inventory (Arvidsson et al., 2016). As pointed out by Persson et al. (Persson, Österberg, Viborg, Jönsson, \& Tenenbaum, 2016), there is currently a lack of knowledge regarding symptomatology of Exhaustion Disorder, influencing the possibility for early detection. The development of diagnostic tools (e.g., LUCIE) (Persson et al., 2016) could aid in early detection and prevention of long periods of sick-leave and rehabilitation.

\section{Separation Between Work and Spare Time, and Recovery from Work}

The boundaries between work and spare time are particularly significant for teachers in Sweden, considering the work/time distribution previously mentioned. Separation between work and spare time had mostly to do with having enough energy to take care of private matters and being able to relax at home.

The way teachers' work is organized could potentially lead to difficulties for teachers to detach psychologically from work and consequently to experience diminished possibilities for recovery from work. Indeed, over one third of the teachers in this study reported that they did not feel that they got enough rest between work days. Although, there were no significant gender or age differences in the data, there was, as could be expected, evidence that women who had children residing at home reported less rest between work days, compared to women who did not have children residing at home. Furthermore, a national government work environment survey with over 10,000 people of the employed population aged 16-64 showed an overall $11 \%$ incidence rate of respondents who reported that they didn't feel that they got enough rest between work days. Stratified according to level of education, the corresponding incidence rate was 15\%. The teachers in this study consequently reported the prevalence of not enough rest between work days to be more than twice as high as than the national statistic. The results are hence in line with results from a previous study on primary and lower secondary school teachers in Sweden, in which the lack of possibilities for recuperation from work was found to be associated with burnout (Arvidsson et al., 2016). The results may also be viewed in light of research on new ways of working (Demerouti, Derks, Lieke, \& Bakker, 2014), which indicates that blurred boundaries between work and spare time may make it harder for employees to switch off from work and find the necessary time for recovery. 


\section{Estimation of Work Ability and Sick Leave}

The majority (78\%) of the teachers in this study estimated that they would still be able to work as teachers two years from now. Again, there were no observed gender or age differences. This can be compared with the study on dental nurses mentioned above, showing a prevalence of $83 \%$. Like dental nurses, teachers showed high levels of stress-related symptoms (Nyqvist et al., 2016).

In this study, $30 \%$ of the respondents reported that they had no sick-days at all during the past 12 months, compared to $41 \%$ in a national population sample. Worth noting is that "Sick presence" (being present at work in spite of being sick) among teachers has previously been reported to be higher than in other professions (Aronsson \& Gustafsson, 2002).

\section{Health Variables in Relation to Work Environment Variables}

In the multivariate analysis, separation between work and spare time was, together with recovery from work, found to partially mediate the relationship between, respectively, job satisfaction and well-being and health complaints. This suggests that separation between work and spare time, and possibilities for recovery from work, are important links between teachers' job satisfaction and their individual health and well-being. The boundary between work and spare time is, as mentioned previously, particularly significant for Swedish teachers, as during school terms they have a 45-hour work week, of which a substantial component is expected to be done at home. In detail, separation between work and spare time has, for the teachers in the study, to do mostly with having the energy to take care of private matters and being able to relax at home. Presumably, having to work from home will have these consequences. These results are in line with previous research on work-life balance pointing to the importance of recovery from work, but nevertheless signify an important aspect of teachers' working life in Sweden.

\section{Conclusions}

Teachers' perceptions of well-being were assessed with a comprehensive battery of health and work-related questions. The results give evidence of a moderate relationship between (a) well-being and (b) quantitative demands, role clarity, physical work environment, and collegial and workplace communication. There is also moderate support for the two models used to analyze the relative importance of separation between work and spare time, as well as recovery from work, for the association between job satisfaction and the outcome variables - well-being and health complaints. Especially disconcerting are results indicative of problems with teachers' lack of recovery between work days, and insufficient separation between work and spare time. The results confirm previous research pointing to teachers in Sweden as being a vulnerable occupational group.

Radically altering the demands of teaching may prove difficult. In light of this, teachers need to find strategies for setting boundaries between work and spare time, as well as finding time to recover from work. In addition, decision-makers should prioritize the development of school-anchored resources to counteract demands experienced by teachers today. 


\section{Limitations}

A limitation of this study is that the research partnership with two municipalities was established through a broad call for interest and is therefore a volunteer sampling. This introduced potential bias, in that the researchers cannot be aware of why the research partner volunteers to participate. Another limitation is that only public schools were sampled. As an increasingly large proportion of teachers in Sweden work in independent schools, it is important that future studies direct their attention to work-related health and working conditions in these schools.

Research designs based on self-report measures are often criticized for introducing common method variance (Podsakoff, MacKenzie, \& Podsakoff, 2012). This is an appropriate concern; on the other hand, self-report methods have shown to adequately assess people's perceptions of work and health, and are therefore valuable despite their limitations (Ashforth, 1985).

Taking into account the cross-sectional design of the study and that an appropriate temporal separation among the predictor, the mediators, and the outcomes can be difficult to achieve in a school setting due to fluctuations in workload over the school year and high turnover, it would, however, be beneficial to collect longitudinal data (Cole \& Maxwell, 2003). As we only tested the mediating effect of two factors, future studies might also include other relevant factors.

\section{Abbreviations \\ DSM, Diagnostic and Statistical Manual of Mental Disorders; ICD-10-SE, Interna- tional Statistical Classification of Diseases and Related Health Problems - Tenth Revision, Swedish edition; WHO, World Health Organization.}

\section{Acknowledgements}

We would like to thank the participating teachers.

\section{References}

Andersson, K. (1998). Epidemiological approach to indoor air problems. Indoor Air, 8(S4), 32-39. https://doi.org/10.1111/j.1600-0668.1998.tb00005.xAndersson, K. (1998). Epidemiological approach to indoor air problem

Arbetsmiljöverket. (2014a). Arbetsmiljön 2013, The Work Environment 2013 (2014:3). Retrieved from https://www.av.se/globalassets/filer/statistik/arbetsmiljostatistik-arbetsmiljon-2013-rapport-2014-03.pdf

Arbetsmiljöverket. (2014b). Arbetsorsakade besvär 2014. Work-related disorders 2014 (2014:4). Retrieved from https:/www.av.se/globalassets/filer/statistik/arbetsmiljostatistik-arbetsorsakadebesvar-rapport-2014.pdf

Arbetsmiljöverket. (2016). Arbetsorsakade besvär 2016. Work-related disorders 2016 (2016:3). Retrieved from https://www.av.se/globalassets/filer/statistik/arbetsorsakade-besvar-2016/ arbetsmiljostatistik-arbetsorsakade-besvar-2016-rapport-2016-3.pdf

Aronsson, G., \& Gustafsson, K. (2002). Sjuknärvaro - förekomst och utvecklingstendenser. (Arbete och Hälsa 2002:8). Retrieved from Stockholm: http://hdl.handle.net/2077/4285

Arvidsson, I., Håkansson, C., Karlson, B., Björk, J., \& Persson, R. (2016). Burnout among Swedish school teachers - A cross-sectional analysis. BMC Public Health, 16(823), 1-11. https://doi.org/10.1186/s12889-016-3498-7 
Ashforth, B. E. (1985). Climate formation: Issues and extensions. Academy of Management Review, 10(4), 837-847. https://doi.org/10.5465/amr.1985.4279106

Bech,P.(1999).Health-relatedqualityoflifemeasurementsintheassessmentofpainclinicresults.ActaAnaesthesiologica Scandinavica, 43(9), 893-896. https://doi.org/10.1034/j.1399-6576.1999.430906.x

Bech, P., Olsen, L. R., Kjoller, M., \& Rasmussen, N. K. (2003). Measuring well-being rather than the absence of distress symptoms: A comparison of the SF-36 Mental Health subscale and the WHO-Five well-being scale. International Journal of Methods in Psychiatric Research, 12(2), 8591. https://doi.org/10.1002/mpr.145

Byrne, B.M. (1999). The nomological network of teacher burnout: A literature review and empirically validated model. In R. Vandenberghe \& A. M. Huberman (Eds.), Understanding and preventing teacher burnout (pp. 15-37). Cambridge: Cambridge University Press. https://doi.org/10.1017/CBO9780511527784.003

Chida, Y., \& Steptoe, A. (2008). Positive psychological well-being and mortality: A quantitative review of prospective observational studies. Psychosomatic Medicine, 70(7), 741756. https://doi.org/10.1097/PSY.0b013e31818105ba

Cole, D.A., \& Maxwell, S.E. (2003). Testing mediational models with longitudinal data: Questions and tips in the use of structural equation modeling. Journal of Abnormal Psychology, 112(4), 558-577. https://doi.org/10.1037/0021-843X.112.4.558

Cortina, L.M., Magley, V.J., Williams, J.H., \& Langhout, R.D. (2001). Incivility in the workplace: incidence and impact. Journal of Occupational Health Psychology, 6(1), 64-80. https://doi.org/10.1037//1076-8998.6.1.64

Day, C., Stobart, G., Sammons, P., Kington, A., Gu, Q., Smees, R., \& Mujtaba, T. (2006). Variations in teachers' work, lives and effectiveness (743). https://doi.org/10.1037/e615332007-001

Demerouti, E., Derks, D., Lieke, L., \& Bakker, A.B. (2014). New ways of working: Impact on working conditions, work-family balance, and well-being. In C. Korunka \& P. Hoonakker (Eds.), The impact of ICT on quality of working life (pp. 123-141). Dordrecht: Springer. https://doi.org/10.1007/978-94-017-8854-0_8

Diener, E., Heintzelman, S.J., Kushlev, K., Tay, L., Wirtz, D., Lutes, L.D., \& Oishi, S. (2017). Findings all psychologists should know from the new science on subjective well-being. Canadian Psychology/ psychologie canadienne, 58(2), 87-104. https://doi.org/10.1037/cap0000063

Diener, E., Oishi, S., \& Lucas, R.E. (2003). Personality, culture, and subjective well-being: Emotional and cognitive evaluations of life. Annual Review of Psychology, 54, 403-425. https://doi.org/10.1146/annurev.psych.54.101601.145056

Dollard, M.F., \& Bakker, A.B. (2010). Psychosocial safety climate as a precursor to conducive work environments, psychological health problems, and employee engagement. Journal of Occupational and Organizational Psychology, 83(3), 579-599. https://doi.org/10.1348/096317909X470690

Eriksson, I., Undén, A.-L., \& Elofsson, S. (2001). Self-rated health. Comparisons between three different measures. Results from a population study. International Journal of Epidemiology, 30(2), 326-333. https://doi.org/10.1093/ije/30.2.326

Eurofond. (2013). Third European Quality of Life Survey - Quality of life in Europe: Subjective wellbeing. Retrieved from Luxembourg: https://digitalcommons.ilr.cornell.edu/cgi/viewcontent. cgi?referer=http://www.google.se/url? sa =t\&rct=j\&q=\&esrc=s\&source=web\&cd=4\&ved=0ahU KEwiJncDB5-nZAhXDfiwKHUtaAyoQFgg0MAM\&url=http\%3A\%2F\%2Fdigitalcommons.ilr. cornell.edu\%2Fcgi\%2Fviewcontent.cgi\%3Farticle\%3D1318\%26context\%3Dintl\&usg=AOvVaw 33n5-CpKFUrKBHa74AhoxA\&httpsredir=1\&article=1318\&context=intl

Folkhälsomyndigheten. (2016). Folkhälsan i sverige 2016, årlig rapportering. Retrieved from https:// www.folkhalsomyndigheten.se/contentassets/cc89748e004743c39ff4c03fec24c570/folkhalsan-isverige-2016-16005.pdf

Fredriksson, S., Kim, J.-L., Torén, K., Kähäri, K., Magnusson, L., \& Waye, K.P. (2016). Preschool teachers have an increased risk of hearing-related symptoms and report more occupational noise exposure compared to randomly selected women. Occupational and Environmental Medicine, 73, A191. https://doi.org/10.1136/oemed-2016-103951.525 
Fromm, J., \& Hagström, U. (2011). Att sova med jobbet: tjänstemännens arbetsvillkor. Retrieved from https://www.tco.se/globalassets/sovamedjobbet.pdf

Försäkringskassan. (2014). Sjukfrånvaro i psykiska diagnoser. En studie av Sveriges befolkning 16-64 år. Retrieved from http://www.forskasverige.se/wp-content/uploads/Sjukfranvaro-PsykiskaDiagnoser-2014.pdf

Hakanen, J.J., \& Schaufeli, W.B. (2012). Do burnout and work engagement predict depressive symptoms and life satisfaction? A three-wave seven-year prospective study. Journal of Affective Disorders, 141(2), 415-424. https://doi.org/10.1016/j.jad.2012.02.043

Hall, T., Krahn, G. L., Horner-Johnson, W., \& Lamb, G. (2011). Examining functional content in widely used Health-Related Quality of Life scales. Rehabilitation Psychology, 56(2), 94-99. https://doi.org/10.1037/a0023054

Hayes, A.F. (2013). Introduction to mediation, moderation, and conditional process analysis: A regression-based approach. New York, NY: The Guilford Press.

Hoaglin, D.C., \& Iglewicz, B. (1987). Fine-tuning some resistant rules for outlier labeling. Journal of the American Statistical Association, 82(400), 1147-1149. https://doi.org/10.1080/01621459.1987.10478551

Johnson, E.O. (2006). Epidemiology of insomnia: From adolescence to old age. Sleep Medicine Clinics, 1(3), 305-317. https://doi.org/10.1016/j.jsmc.2006.06.006

Judge, T.A., Thoresen, C.J., Bono, J.E., \& Patton, G.K. (2001). The job satisfaction-job performance relationship: A qualitative and quantitative review. Psychological Bulletin, 127(3), 376-407. https://doi.org/10.1037//0033-2909.127.3.376

Karlson, B., Jönsson, P., Pålsson, B., Åbjörnsson, G., Malmberg, B., Larsson, B., \& Österberg, K. (2010). Return to work after a workplace-oriented intervention for patients on sickleave for burnout - a prospective controlled study. BMC Public Health, 10(301), 1-10. https://doi.org/10.1186/1471-2458-10-301

Kleinbaum, D.G., Kupper, L.L., \& Morgenstern, H. (1982). Epidemiologic research: principles and quantitative methods. New York, NY: John Wiley \& Sons.

Kloep, M., \& Tarifa, F. (1994). Working conditions, work style, and job satisfaction among Albanian teachers. International Review of Education, 40(2), 159-172. https://doi.org/10.1007/BF01103691

Kristensen, T.S., Hannerz, H., Høgh, A., \& Borg, V. (2005). The Copenhagen Psychosocial Questionnaire - a tool for the assessment and improvement of the psychosocial work environment. Scandinavian Journal of Work, Environment and Health, 31(6), 438-449. https://doi.org/10.5271/sjweh.948

Lärarnas Riksförbund, L. (2013). Lärarnas Riksförbunds arbetsmiljörapport. Retrieved from https://www.lr.se/download/18.1171153f1407143378d5a64/1378450760421/ Arbetsmilj\%C3\%B6rapport_sept2013.pdf

LeBlanc, M., Mérette, C., Savard, J., Ivers, H., Baillargeon, L., \& Morin, C.M. (2009). Incidence and risk factors of insomnia in a population-based sample. Sleep, 32(8), 1027-1037. https://doi. org/10.1093/sleep/32.8.1027

Linton, S. J., Kecklund, G., Franklin, K.A., Leissner, L. C., Sivertsen, B., Lindberg, E., ... Hall, C. (2015). The effect of the work environment on future sleep disturbances: A systematic review. Sleep Medicine Reviews, 23, 10-19. https://doi.org/10.1016/j.smrv.2014.10.010

Loeb, S., Darling-Hammond, L., \& Luczak, J. (2005). How teaching conditions predict teacher turnover in California schools. Peabody Journal of Education, 80(3), 44-70. https://doi.org/10.1207/s15327930pje8003_4

Loyen, A., Van Hecke, L., Verloigne, M., Hendriksen, I., Lakerveld, J., Steene-Johannessen, J., ... Ekelund, U. (2016). Variation in population levels of physical activity in European adults according to cross-European studies: A systematic literature review within DEDIPAC. International Journal of Behavioral Nutrition and Physical Activity, 13(72), 1-18. https://doi.org/10.1186/s12966-016-0398-2

Lundström, U. (2015). Teacher autonomy in the era of New Public Management. Nordic Journal of Studies in Educational Policy, 2015(2), 73-85. https://doi.org/10.3402/nstep.v1.28144

McDowell, I. (2010). Measures of self-perceived well-being. Journal of Psychosomatic Research, 69(1), 69-79. https://doi.org/10.1016/j.jpsychores.2009.07.002 
Miller, N. (2002). Insider change leadership in schools. International Journal of Leadership in Education, 5(4), 343-360. https://doi.org/10.1080/13603120210141951

Molarius, A., Granström, F., Lindén-Boström, M., \& Elo, S. (2014). Domestic work and self-rated health among women and men aged 25-64 years: Results from a population-based survey in Sweden. Scandinavian Journal of Social Medicine, 42(1), 52-59. https://doi.org/10.1177/1403494813503056

Nordin, M., Åkerstedt, T., \& Nordin, S. (2013). Psychometric evaluation and normative data for the Karolinska Sleep Questionnaire. Sleep and Biological Rhythms, 11(4), 216-226. https://doi.org/10.1111/sbr.12024

Nübling, M., Vomstein, M., Haug, A., Nübling, T., \& Adiwidjaja, A. (2011). European-wide survey on teachers work related stress-assessment, comparison and evaluation of the impact of psychosocial hazards on teachers at their workplace. Retrieved from https://csee-etuce.org/images/attachments/WRS_europe_191211_final2.pdf

Nyqvist, E., Arnrup, K., \& Berthelsen, H. (2016). Belastningssymtom och sviktande arbetsförmåga. Tandläkartidningen, 14, 54-61.

Ohayon, M. M., \& Bader, G. (2010). Prevalence and correlates of insomnia in the Swedish population aged 19-75 years. Sleep Medicine, 11(10), 980-986. https://doi.org/10.1016/j.sleep.2010.07.012

Persson, R., Österberg, K., Viborg, N., Jönsson, P., \& Tenenbaum, A. (2016). The Lund University Checklist for Incipient Exhaustion - a cross-sectional comparison of a new instrument with similar contemporary tools. BMC Public Health, 16(350), 1-12. https://doi.org/10.1186/s12889-016-3001-5

Podsakoff, P.M., MacKenzie, S.B., \& Podsakoff, N.P. (2012). Sources of method bias in social science research and recommendations on how to control it. Annual Review of Psychology, 63, 539-569. https://doi.org/10.1146/annurev-psych-120710-100452

Richter, A., Näswall, K., Lindfors, P., \& Sverke, M. (2015). Job insecurity and work-family conflict in teachers in Sweden: Examining their relations with longitudinal cross-lagged modeling. PsyCh Journal, 4(2), 98-111. https://doi.org/10.1002/pchj.88

Rizzo, J.R., House, R.J., \& Lirtzman, S.I. (1970). Role conflict and ambiguity in complex organizations. Administrative Science Quarterly, 15(2), 150-163. https://doi.org/10.2307/2391486

Roth, T. (2007). Insomnia: definition, prevalence, etiology, and consequences. Journal of Clinical Sleep Medicine, 3(5 Suppl), S7-10. Retrieved from https://www.ncbi.nlm.nih.gov/pubmed/17824495 https://www.ncbi.nlm.nih.gov/pmc/articles/PMC1978319/pdf/jcsm.3.5.s7.pdf

Ryff, C.D., \& Singer, B. (1998). The contours of positive human health. Psychological Inquiry, 9(1), 1-28. https://doi.org/10.1207/s15327965pli0901_1

Salovey, P., Rothman, A. J., Detweiler, J. B., \& Steward, W. T. (2000). Emotional states and physical health. American Psychologist, 55(1), 110-121. https://doi.org/10.1037//0003-066X.55.1.110

SBU. (2014). Arbetsmiljöns betydelse för symtom på depression och utmattningssyndrom. En systematisk litteraturöversikt (223). Retrieved from Stockholm: http://www.sbu.se/contentassets/800ad 7aecf9146c795d3a89c7a957048/arbetsmiljo_depression_2014.pdf

Schad, E. (2019a). No time to talk! Teachers' perceptions of organizational communication: Context and climate. Educational Management Administration \& Leadership, 47(3), 421-442. https://doi.org/10.1177/1741143217739358

Schad, E. (2019b). Lacking structures of communication for teachers in Sweden, a focus group study. Lund Psychological Reports, 9(2), 1-20.

Schaufeli, W. B., Bakker, A. B., \& Van Rhenen, W. (2009). How changes in job demands and resources predict burnout, work engagement, and sickness absenteeism. Journal of Organizational Behavior, 30(7), 893-917. https://doi.org/10.1002/job.595

Sisask, M., Värnik, P., Värnik, A., Apter, A., Balazs, J., Balint, M., .. Cosman, D. (2014). Teacher satisfaction with school and psychological well-being affects their readiness to help children with mental health problems. Health Education Journal, 73(4), 382-393. https://doi.org/10.1177/0017896913485742

Skaalvik, E.M., \& Skaalvik, S. (2009). Does school context matter? Relations with teacher burnout and job satisfaction. Teaching and Teacher Education, 25(3), 518-524. https://doi.org/10.1016/j. tate.2008.12.006 
Socialstyrelsen. (2003). Utmattningssyndrom. Stressrelaterad psykisk ohälsa. Retrieved from Stockholm https://www.socialstyrelsen.se/Lists/Artikelkatalog/Attachments/10723/2003-123-18_200312319.pdf

Taloyan, M., Leineweber, C., Hyde, M., \& Westerlund, H. (2015). Self-rated health amongst male and female employees in Sweden: A nationally representative study. International Archives of Occupational and Environmental Health, 88(7), 849-859. https://doi.org/10.1007/s00420-014-1014-x

Topp, C.W., Østergaard, S.D., Søndergaard, S., \& Bech, P. (2015). The WHO-5 Well-Being Index: A systematic review of the literature. Psychotherapy and Psychosomatics, 84(3), 167-176. https://doi.org/10.1159/000376585

Toumi, K., Illmarinen, J., Jahkola, A., Katajarinne, L., \& Tulkki, A. (1998). Work Ability Index. Swedish version (2nd ed.). Helsinki: Finnish Institute of Occupational Health.

Travers, C. (2017). Current knowledge on the nature, prevalence, sources and potential impact of teacher stress. In T. McIntyre, S. McIntyre, \& D. Francis (Eds.), Educator stress. aligning perspectives on health, safety and well-being (pp. 23-54). Cham: Springer. https://doi.org/10.1007/978-3-319-53053-6_2

Törnroos, M., Hakulinen, C., Hintsanen, M., Puttonen, S., Hintsa, T., Pulkki-Råback, L., ... Keltikangas-Järvinen, L. (2017). Reciprocal relationships between psychosocial work characteristics and sleep problems: A two-wave study. Work and Stress, 31(1), 63-81. https://doi.org/10.1080/02678373.2017.1297968

Walsh, J.K., Coulouvrat, C., Hajak, G., Lakoma, M. D., Petukhova, M., Roth, T., ... Stephenson, J. J. (2011). Nighttime insomnia symptoms and perceived health in the America Insomnia Survey (AIS). Sleep, 34(8), 997-1011. https://doi.org/10.5665/SLEEP.1150

Warburton, D. E., Nicol, C. W., \& Bredin, S. S. (2006). Health benefits of physical activity: The evidence. Canadian Medical Association Journal, 174(6), 801-809. https://doi.org/10.1503/cmaj.051351

WHO. (1948). Constitution of the World Health Organization. Geneva: World Health Organization.

WHO. (2010). Global recommendations on physical activity for health. Retrieved from http://apps.who.int/iris/bitstream/10665/44399/1/9789241599979_eng.pdf

Åkerstedt, T., Garefelt, J., Richter, A., Westerlund, H., Magnusson Hanson, L. L., Sverke, M., \& Kecklund, G. (2015). Work and sleep - A prospective study of psychosocial work factors, physical work factors, and work scheduling. Sleep, 38(7), 1129-1136. https://doi.org/10.5665/ sleep. 4828

Original manuscript received August 20, 2019

Revised manuscript accepted October 15, 2019

First published online November 15, 2019

To cite this article: Schad, E., Johnsson, P. (2019). Well-Being and Working Conditions of Teachers in Sweden. Psychology in Russia: State of the Art, 12(4), 23-46. DOI: 10.11621/ pir.2019.0402 